\title{
Multi-metal resistance study of bacteria highly resistant to mercury isolated from dental clinic effluent
}

\author{
Parisa Keramati ${ }^{1}$, Mehran Hoodaji ${ }^{1}$ and Arezoo Tahmourespour ${ }^{2 *}$ \\ ${ }^{1}$ Soil Science Department, Khorasgan (Isfahan) branch, Islamic Azad University,Isfahan, Iran \\ ${ }^{2}$ Basic Medical Sciences Department, Khorasgan (Isfahan) branch, Islamic Azad University, Isfahan, Iran. \\ Accepted 18 February, 2011
}

\begin{abstract}
Heavy metals pollution represents an important environmental problem. One of these metals is mercury. The aim of this research was isolating bacteria highly resistant to mercury from dental clinic effluent to investigate their growth potential in the presence of other heavy metals, such as $\mathrm{Zn}, \mathrm{Cu}, \mathrm{Ni}$, $\mathrm{Ag}, \mathrm{Cd}$ and $\mathrm{Pb}$. Three dental wastewater samples were selected and their mercury concentrations, $\mathrm{pH}$, $\mathrm{EC}, \mathrm{BOD}_{5}$ and COD were determined. The mercury-resistant bacteria were found to belong to the genera of Pseudomonas, Proteus, Citrobacter, Bacillus, Corynebacterium and Staphylococcus. In examining multi-metal resistances, the pattern of hexa-R was seen in the case of Citrobacter and Pseudomonas genera. The highest tolerated concentration of heavy metals was $25.6 \mathrm{mM}$ which is related to $\mathrm{Ag}$ and $\mathrm{Cu}$ and tolerated by Citrobacter isolate. It is also indicated that Citrobacter was the most resistant isolates to $\mathrm{Cd}$ with significant difference $(\mathrm{P}<0.05)$. Results of this study demonstrate the occurrence of different groups of bacteria, capable of high tolerance to mercury with a potential to tolerate a variety of other toxic heavy metals suggest that, resistance to many types of toxicants may be present in the same organism; therefore, such organisms have high potential for biotechnology purposes.
\end{abstract}

Key words: Bacteria, dental effluent, heavy metal, mercury, multi-metal resistance.

\section{INTRODUCTION}

Heavy-metals are widely used in chemistry and engineering. There is increasing interest in the biotechnology of extraction of rare metals from primary and secondary raw materials (Korenevskii et al., 1997). On the other hand, heavy metals are very toxic elements, which comprise the essential part of anthropogenic pollutants (Avtsyn et al., 1991). The presence of toxic heavy metal contaminants in aqueous streams, arising from the discharge of untreated metal containing effluents into water bodies, is one of the most important environmental issues (Rehman et al., 2008). The discharge of heavy metals into the environment as a result of agricultural, industrial and military operations, and the effects of this pollution on ecosystems and human health have been of concern for some years (Essa et al., 2002). These heavy metals include

*Corresponding author. E-mail: atahmoures@khuisf.ac.ir, arezootahmourespour@gmail.com. Tel: 0983116278314. Fax: 00983115354045. cadmium, chromium, cobalt, manganese, mercury, nickel, silver, and zinc. Metal-polluted industrial effluents discharged into sewage treatment plants could lead to high metal concentrations in the activated sludge. Microbial populations in metal-polluted environments contain microorganisms that have adapted to the toxic concentrations of heavy metals and become "metal resistant" (Leung and Chua, 2001).

Interest in processes involving heavy metal uptake by micro-organisms has increased considerably in recent years, in particular because of the biotechnological potential of micro-organisms in metal removal and/or recovery (Lopez-Errasquin and Vazquez, 2003). Mercury is one of the most toxic heavy metals in the environment, commonly found in the global environment including lithosphere, hydrosphere, atmosphere and biosphere and its toxic nature has been known for centuries (Miretzky and Fernandez Cirelli, 2009). Mercury and its allied compounds are extremely toxic in the environment, because of its many unique properties, the use and dispersion of mercuric compounds have increased vastly, resulting in extensive heavy metal pollution (Renzoni 
et al., 1998).

Mercury is recognized as a potent and widely distributed toxicant in the global environment having ability to accumulate at various levels of food chain (Jan et al., 2009). Mercury poisoning has became a problem of current interest as a result of environmental pollution on a global scale (Fitzgerald and Lamborg, 2005; Parta and Sharma, 2008). Mercury pollution is a ubiquitous problem in the present day world, as mercury concentration are rising continuously as a result of increased industrial, medicinal and domestic use of mercury (Jan et al., 2009). Exposure to mercury can come from a number of different roots, such as through dental amalgam fillings. Dental amalgam is the most commonly used dental restorative material used for dental fillings and currently, they are composed of about $50 \%$ mercury (Davis, 2003). American Dental Association (2005) in a mass balance assessment of the annual amount of amalgam discharged in dental wastewater reported that, about 29.7 tons of mercury in the form of amalgam was discharged into dental units by dental offices.

Therefore, dental clinic wastewater contains mercury and mercury resistant bacteria. Conventional techniques for removing dissolved toxic metals include chemical precipitation and sludge separation, chemical oxidation or reduction, ion exchange, reverse osmosis, filtration, adsorption using activated charcoal, electrochemical treatment and evaporative recovery may not be effective, especially when the metal concentration is lower than $100 \mathrm{mgL}^{-1}$. Also, these techniques can be expensive, they may not always be feasible and their metal-binding properties are non-specific. So, the use of microorganisms in the removal of metals from contaminated wastewater, mining, and industrial wastes is generally considered promising. These are the reasons why alternative processing methods, such as those using microbial biomass, are now being considered more seriously (Lopez-Errasquin and Vazquez, 2003; GreenRuiz, 2006). Bioremediation techniques that involve the use of microorganisms to remove environmental contaminants have gained an increasing interest in the last few years (Gupta and Ali, 2003). Staphylococcus, Bacillus, Pseudomonas, Citrobacteria, Klebsiella, and Rhodococcus are organisms commonly used in bioremediation mechanisms (Adeniji, 2004). There are three classes of bioremediation: 1) Biotransformation, 2) Biodegradation and 3) Mineralization. These three classifications can occur either in situ (at the site of contamination) or ex situ (contaminant taken out of the site of contamination and treated elsewhere) (Leung, 2004). Metal-resistant microorganisms may be useful as indicators of potential toxicity to other forms of life (Doelman et al., 1994). Bacterial resistance to mercury in the environment is one of the numerous examples of the genetic and physiological adaptability of microbial communities exposed to contaminants (Ramond et al., 2009). The present study was aimed to isolate mercury resistant bacteria from dental clinic wastewater and investigate their potential for growth in the presence of 6 different heavy metals such as Nickel, Lead, Copper, Zinc, Cadmium and Silver; because these heavy metals are present in many environments and so, the remediation of these metals is one of great ecological interests.

\section{MATERIALS AND METHODS}

\section{Wastewater sampling and culture condition}

Three dental clinic effluents were selected from training section (sample 1), restorative section (sample 2) and an existing unit waterline (sample 3) of the dental faculty of Islamic Azad University Khorasgan branch (Esfahan) during November and September 2009. The samples were transferred to a laboratory in sterile-dark Pyrex flasks at $4{ }^{\circ} \mathrm{C}$ and processed within 18 to $24 \mathrm{~h}$. The properties such as temperature, $\mathrm{pH}, \mathrm{EC}, \mathrm{COD}, \mathrm{BOD}_{5}$ were determined. Also, mercury contents were measured by cold vapor atomic absorption spectrophotometer (Buck Scientific). The samples were inoculated on PHG Agar medium [peptone $(4 \mathrm{~g} / \mathrm{L})$, yeast extract $(1 \mathrm{~g} / \mathrm{L})$, glucose $(2 \mathrm{~g} / \mathrm{L}), \mathrm{NaCl}(5 \mathrm{~g} / \mathrm{L})$, Agar $(15 \mathrm{~g} / \mathrm{L})]$, (supplemented with $0.05 \mathrm{mM}(\approx 10 \mathrm{ppm}) \mathrm{HgCl}_{2}$ ) and incubated at $35^{\circ} \mathrm{C}$ for $48 \mathrm{~h}$.

\section{MIC determination}

Mercury-resistant bacteria (MRB) from wastewater samples were isolated by growth on PHG Agar and PHG Broth amended by 10 ppm mercuric chloride (Merck, Germany). For determining MIC (Minimum Inhibitory Concentration) and adaptation, the PHG agar plates supplemented with different concentration of $\mathrm{HgCl}_{2}$ were inoculated aseptically with a culture of isolated MRBs (15 isolates) in exponential growth phase and incubated for $48 \mathrm{~h}$ (MIC) and 7 to 10 days (adaptation). 6 isolates out of these 15 MRBs were selected and hereafter designated as bacteria highly resistant to mercury (BHRM). Gram staining and biochemical testes of BHRMs were done for probable identification.

\section{Multi-metal resistance pattern of BHRM}

To determine multi-metal resistance, PHG-II agar plates supplemented with heavy metals were used. Resistant colonies to mercury (BHRMs) were inoculated in radial streaks on PHG agar media supplemented with each heavy metal such as $\mathrm{Pb}\left(\mathrm{NO}_{3}\right)_{2}$, $\mathrm{Ag}\left(\mathrm{NO}_{3}\right), \mathrm{ZnCl}, \mathrm{Ni}\left(\mathrm{NO}_{3}\right)_{2} \cdot 6 \mathrm{H}_{2} \mathrm{O}$ and $\mathrm{Cd}\left(\mathrm{NO}_{3}\right)_{2} \cdot 4 \mathrm{H}_{2} \mathrm{O}$. Each metal concentration in PHG agar medium was $0.4,0.8,1.6,3.2,6.4,12.8$ and $25.6 \mathrm{mM}$. For each step, the plates were incubated at $35^{\circ} \mathrm{C}$ for $48 \mathrm{~h}$ and growth was investigated. Then, the grown colonies transferred to a media with higher concentration of the same metal.

\section{Statistical analysis}

Observations were made and all the experiments run in triplicate. The experimental groups were compared and significant differences evaluated by using the variance analysis (ANOVA) and Duncan by SPSS software (ver.18). In order to draw charts, Excel software was used. Statistical significance was assumed at a $P$ value of 0.05 .

\section{RESULT}

The chemical properties of three effluent samples are 
Keramati et al.

833

Table 1. The analysis of selected samples.

\begin{tabular}{lccccc}
\hline \multicolumn{1}{c}{ Analysis } & Mercury content $\left(\mathbf{m g} \cdot \mathbf{L}^{-1}\right)$ & $\mathbf{p H}$ & $\mathbf{E C}\left(\mathbf{d S} \cdot \mathbf{m}^{-1}\right)$ & COD $\left(\mathbf{m g} \cdot \mathbf{L}^{-1}\right)$ & BOD $_{5}\left(\mathbf{m g} \cdot \mathbf{L}^{-1}\right)$ \\
\hline Sample & 3.55 & 7.53 & 0.32 & 157 & 32 \\
2 (Training section effluent) & 47.8 & 7.65 & 0.3 & 272 & 55 \\
3 (Existing unit waterline effluent) & 0.12 & 7.26 & 0.29 & 134 & 25 \\
\hline
\end{tabular}

Table 2. The MIC and adaptation of MRBs to different concentrations of $\mathrm{HgCl}_{2}$.

\begin{tabular}{|c|c|c|c|c|c|c|}
\hline $\begin{array}{l}\text { Strain } \\
\text { Concentration } \\
\text { (mM) }\end{array}$ & $\begin{array}{c}\text { Citrobacter } \\
\text { (intermedius) }\end{array}$ & $\begin{array}{c}\text { Pseudomonas } \\
\text { (mallei) }\end{array}$ & $\begin{array}{l}\text { Proteus } \\
\text { (mirabilis) }\end{array}$ & $\begin{array}{l}\text { Staphylococcus } \\
\text { (aureus) }\end{array}$ & $\begin{array}{c}\text { Bacillus } \\
\text { (megaterium) }\end{array}$ & $\begin{array}{c}\text { Corynebacterium } \\
\text { (xerosis) }\end{array}$ \\
\hline 0.2 & + & + & + & + & + & + \\
\hline 0.4 & + & + & + & $\boldsymbol{+}(\mathrm{MIC})$ & + & + \\
\hline 0.8 & + & + & + & $+a$ & + & $+(\mathrm{MIC})$ \\
\hline 1.6 & + & $+(\mathrm{MIC})$ & $+(\mathrm{MIC})$ & $+a$ & + & $+{ }^{a}$ \\
\hline 3.2 & $+(\mathrm{MIC})$ & $++^{a}$ & $+{ }^{a}$ & $+a$ & $+(\mathrm{MIC})$ & $++^{a}$ \\
\hline 6.4 & $+{ }^{a}$ & $+{ }^{a}$ & $++^{a}$ & $+a$ & $+{ }^{a}$ & $+{ }^{a}$ \\
\hline 12.8 & $+{ }^{a}$ & - & $++^{a}$ & $++^{a}$ & $++^{a}$ & - \\
\hline 25.6 & $+^{a}$ & - & - & - & $+{ }^{a}$ & - \\
\hline 51.2 & & & & & & \\
\hline
\end{tabular}

+: growth (24-48h); - : no growth; a : growth after 7 to 10 days (adaptation).

Table 3. Multi-metal resistance pattern of BHRMs.

\begin{tabular}{lcccccccc}
\hline Strain & Type of multiple resistance & Zn & $\mathbf{C d}$ & $\mathbf{C u}$ & $\mathbf{N i}$ & $\mathbf{P b}$ & $\mathbf{A g}$ & $\mathbf{g}$ \\
\hline Citrobacter & Hexa- R & + & + & + & + & + & + & \\
Pseudomonas & Hexa- R & + & + & + & + & + & + & \\
Proteus & penta-R & + & - & + & + & + & + & \\
Bacillus & penta_R & + & - & + & + & + & + & \\
Corynebacterium & penta-R & + & - & + & + & + & + & \\
Staphylococcus & Tri-R & - & - & + & - & + & + & \\
\hline
\end{tabular}

+: growth on $\geq 3.2 \mathrm{mM}$; - : no growth or growth on $<3.2 \mathrm{mM}$.

shown in Table 1. It is clear that sample 2 (restorative section) was the most polluted samples with significant difference $(P<0.05)$. 15 mercury resistant bacteria (MRB) were isolated by growth on PHG Agar supplemented with $10 \mathrm{ppm}$ mercuric chloride. The MIC and adaptation of MRBs to different concentrations of $\mathrm{HgCl}_{2}$ were investigated and shown in Table 2. 6 isolates out of these 15 MRBs were highly resistant to mercury and designated as BHRM. The maximum MIC and adaptation were 3.2 and $25.6 \mathrm{mM} / \mathrm{L}$, respectively which are related to such bacteria as Citrobacter and Bacillus. The minimum MIC was $0.4 \mathrm{mM} / \mathrm{L}$ that is of Staphylococcus. In examining multi-metal resistances, the pattern of hexa- $R$ were seen in the case of Citrobacter and Pseudomonas genera. The Proteus, Bacillus and Corynebacterium isolates could not resist in high concentration ( $\geq 3.2 \mathrm{mM} / \mathrm{L})$ of $\mathrm{Cd}$ and their multimetal resistance pattern was penta $-R$ (Table3).

The results of minimum inhibitory concentration of 6 different heavy metals is shown in Figure 1. In all cases, 
Cd

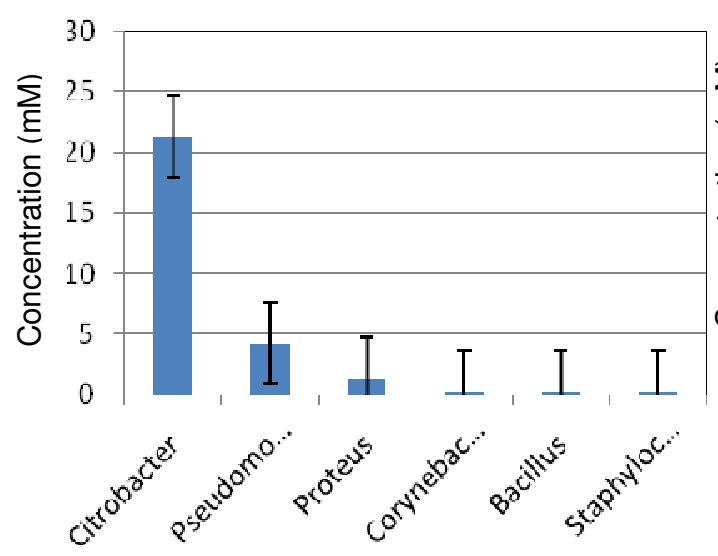

$\mathrm{Pb}$

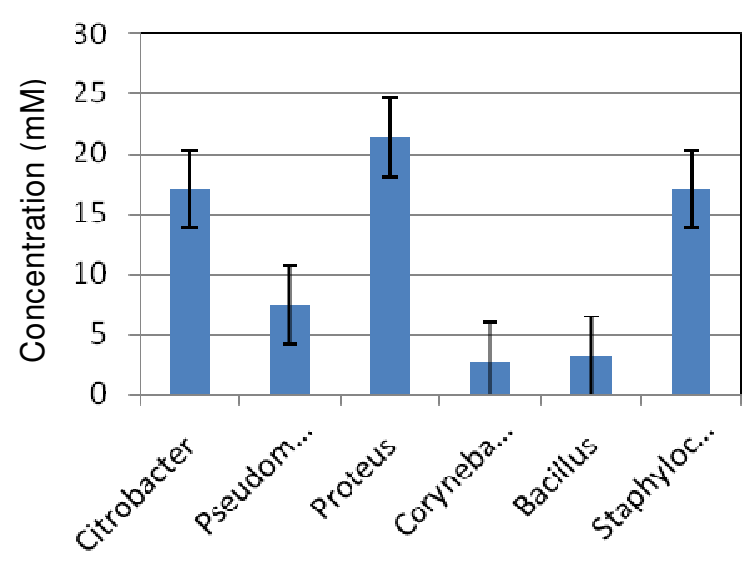

$\mathrm{Cu}$

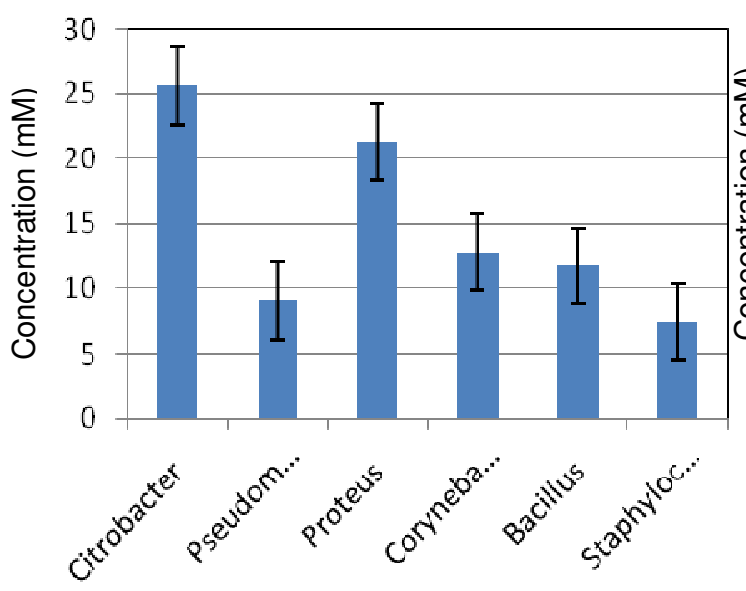

$\mathrm{Ni}$

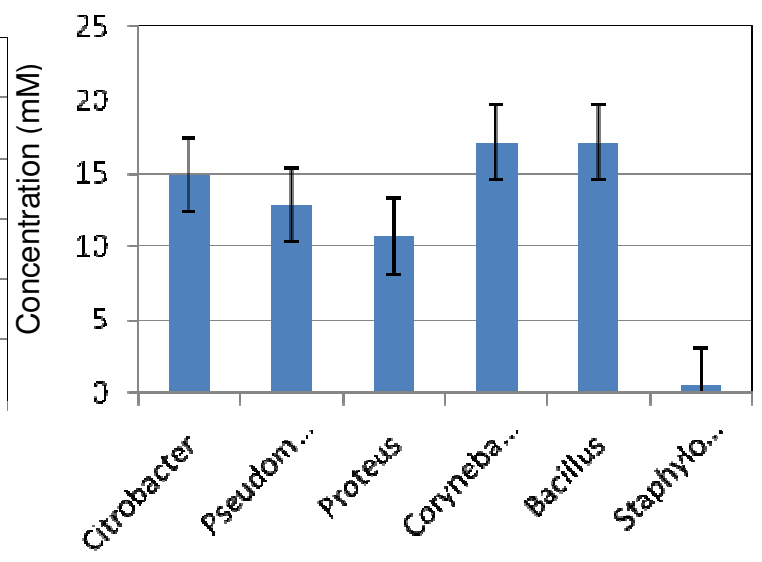

$\mathrm{Zn}$

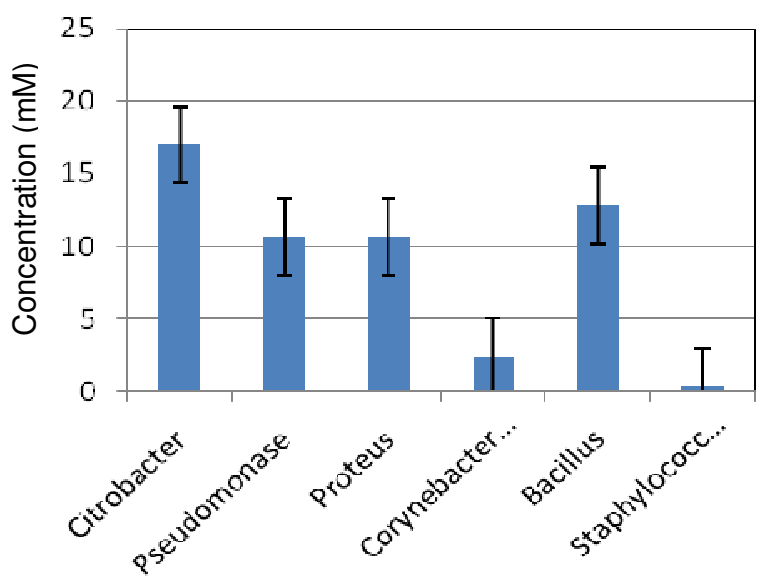

$\mathrm{Ag}$

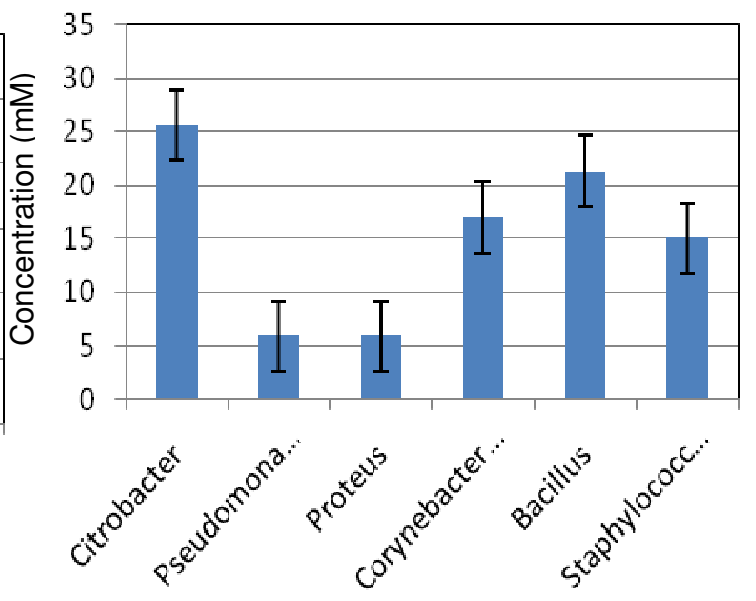

Figure 1. The MIC comparison of BHRMs to different heavy metals.

strains were able to grow in the proximity of BHRM on PHG broth medium containing 6.4 and $25.6 \mathrm{mM} \mathrm{Hg}$ within 7 to 10 days incubation. Minimum inhibitory concentration of other heavy metals was determined at different concentrations of each tested heavy metal within $48 \mathrm{~h}$ incubation. The results indicated that, Citrobacter was the most resistant isolates to $\mathrm{Cd}$ with significant difference $(P<0.05)$. The other isolates had not 
significant differences in Cd tolerance. Staphylococcus isolate was the most sensitive strain to $\mathrm{Ni}$ with significant difference $(P<0.05)$.

\section{DISCUSSION}

The mercury-resistant bacteria (MRB) were isolated and identified from three dental clinic effluents and their mercury MIC and adaptability were determined. At least, 6 isolates of highly resistant bacteria to mercury (BHRM) were selected for investigation of their multi-metal resistance. These isolates included both Gram-positive (e.g. Bacillus) and Gram-negative (e.g. Citrobacter) bacteria. The resistance of these strains to 6 different heavy metals such as copper, lead, zinc, cadmium, silver and nickel were determined with an initial metal concentration of $0.2 \mathrm{mM}$. Such organisms are important in containing the basic biological processes in contaminated habits. The Hg-resistant bacteria can reduce $\mathrm{Hg}^{2+}$ to elemental $\mathrm{Hg}^{0}$ that volatilizes out of the system because of its high vapor presence (Summers and Silver, 1978). Further, some bacteria can detoxify $\mathrm{Hg}$ compounds by the action of organomercural and by mercuric reductase, that reduces $\mathrm{Hg}^{2+}$ to volatile $\mathrm{Hg}$ (Nakamurak and Silver, 1994). Several authors have reported the presence of metallothionein-like proteins in bacterial system that exhibit resistance to several heavy metals like zinc, cadmium, nickel, cobalt and mercury (Robinson et al., 2001; Silver and Ji, 1994). Many bacterial species have been shown to develop resistance to mercury and other heavy metals (Jaysankar and Ramaiah, 2007; Fitzgerad and Lamborg, 2005; Singh et al., 2008). As for microorganisms, there are at least three mechanisms of mercury bioremediation: enzyme reduction to $\mathrm{Hg}^{0}$, volatilization and formation of insoluble HgS (Essa et al., 2002).

Recently, microbial bioremediation has appeared as an alternative technique to such traditional chemical treatments (Brierly, 1990). Microorganisms like bacteria, fungi, algae and actinomycetes have effectively sequestered heavy metals (Wong and So, 1993). These have been used to remove metals from polluted industrial and domestic effluents on a large scale. Microbiological detoxification of polluted water is economical, safe and sustainable (Eccles, 1995). It is well recognized that microorganisms have a high affinity for metals and can accumulate both heavy and toxic metals by a variety of mechanisms (Rehman et al., 2008). In this research, in comparison of multi-metal resistant pattern cleared that, significant differences $(P<0.05)$ were observed between some bacterial strains. For example in lead resistance pattern, a significant difference was observed between Proteus and Corynebacterium, Bacillus and Pseudomonas but there is no significant difference $(P>$ 0.05 ) between Proteus, Citrobacter and Staphylococcus. In these cases, Proteus and Corynebacterium were the most and the least resistant strains respectively. In nickel-resistant pattern, a significant difference was observed between Staphylococcus (the least resistant strain) and all others. Bacillus and Corynebacterium had maximum resistance to nickel. In cadmium-resistant pattern, a significant difference was observed between all of these strains. Citrobacter had maximum resistance and each of the gram-positive bacteria had no resistance. In zinc-resistant pattern, a significant difference was observed between Staphylococcus with other strains except Corynebacterium. Citrobacter had maximum resistance to zinc and Staphylococcus had minimum resistance.

In copper-resistant pattern, a significant difference was observed between Citrobacter with other strains except Proteus. Citrobacter and Staphylococcus showed maximum and minimum resistance respectively. In silverresistant pattern, a significant difference was observed between Pseudomonas and other strains except Proteus. Citrobacter had maximum resistance to silver and Proteus had minimum resistance. In whole, the Citrobacter strain, exhibited the highest tolerance to all tested metals and staphylococcus strain exhibited the lowest tolerance to metals. In previous researches, bacteria like Escherichia coli, Klebsiella, Alcaligenes, Bacillus, Micrococcus, Pseudomonas (Pahan et al., 1990) and Acinetobacter (Petrova et al., 2002) were recognized as mercury resistant bacteria. It was also reported that, clinical isolates of Staphylococcus aureus is resistant to mercury (Jan et al., 2009). Holtz et al. (2005) in a study of mercury resistant bacteria found that, Hg-resistance was almost exclusively restricted to Pseudomonas frederiksbergensis and Pseudomonas migulae groups. In another research on the assimilation and detoxification of selenium and mercury, Pseudomonas fluorscens was a mercury resistant bacteria (Belzile et al., 2006).

In this study, Proteus sp., Citrobacter sp. and Corynebacterium sp. which were not mentioned in previous researches or have not been considered thoughtfully were isolated as mercury-resistant bacteria. The results showed that, mercury colored concentration which the isolates were able to grow in, was much higher than the previous ones. For example, in a study of Jaysankar et al. (2003), bacteria highly resistant to mercury that were isolated from seawater and sediment samples were capable of growth at $50 \mathrm{ppm}$ of mercury. Also, Ready et al. (2007) investigated the effect of amalgams exposure on mercury resistant bacteria, the mercury chloride was used at concentrations ranging from 0.125 to $512 \mu \mathrm{M}$ and bacteria with a $\mathrm{HgCl}_{2} \mathrm{MIC}$ of $\geq$ $325 \mu \mathrm{M}$ were regarded as $\mathrm{Hg}$ resistant. One of the reasons for such high resistance among the isolated bacteria in this study could be related to the way of isolating mercury-resistant bacteria and it is of great import. In most of the past researches, the isolating of mercury-resistant bacteria were done by direct culturing 
in a solid medium containing mercury and a lower degree of resistance was observed (Karbasizadeh et al., 2003; Wagner-Dobler et al., 2003). Mercury-resistant bacteria in this study were isolated by initial enriching with presentation of $10 \mathrm{ppm}$ mercury chloride. Initial enriching adapts bacteria to mercury stress. So, the isolated bacteria would be able to tolerate in even higher concentrations.

Additionally, the bacteria in each stage were incubated after culturing in liquid medium about a week and then transferred to a medium with a higher mercury concentration resulting in bacterial adaptation. The pathways of $\mathrm{Hg}$ modification are not yet understood. The BHRM investigations during this study have many unique characteristics. We find that these dental effluent isolates capable of high resistance to $\mathrm{Hg}$ were able to detoxify many other heavy metals, and this is useful for bioremediation of heavy metals. Mercury levels prescribed by Bureau of Indian standards and WHO after a survey in 2003 are $0.001 \mathrm{mg} / \mathrm{L}$ for drinking water and $0.01 \mathrm{mg} / \mathrm{L}$ for industrial effluents (Jan et al., 2009); and the lowest effluent mercury concentrations for many waste streams in US. EPA (1997) ranging from 0.5 to 50 $\mu \mathrm{g} / \mathrm{L}$, which mercury content measured in these three wastewater samples are more than standards, therefore the high tolerance of isolated bacteria to mercury in this study could be related to the existence of bacteria in dental effluent containing mercury and their adaptation during passing time.

\section{REFERENCES}

Adeniji A (2004). Bioremediation of Arsenic, Chromium, Lead and Mercury. National Network of Environmental Management studies Fellow for U.S. Environmental Protection Agancy Office of Solid Waste and Emergency Response Technology Innovation Office Washington, Dc, pp. 1-43.

Avtsyn AP, Zharoronkov AA, Rish MA, Strochkova LS (1991). Mikroelemenozy Cheloveka (Microelement Diseases in Humans). Moscow: Medistsyna, pp. 1-496.

American Dental Association (ADA) (2005). Summary of Recent Study of Dental Amalgam in Wastewater. repared by the American Dental Association. Available on www.ada.org.

Belzile N, Jun Wu G, Chen YW, Appanna VD (2006). Detoxification of selenite and mercury by reduction and mutual protection I $\mathrm{n}$ the assimilation of both elements by Pseudomonas fluoresens. Sci. Total Environ., 367: 704-714.

Brierly CL (1990). Bioremediation of Metal Contaminated surface and Ground Water. J. Geomicrobial., 8: 201-233.

Davis JR (2003). Handbook of Materials for Medical Devices, ASM International.

Doelman P, Jansen E, Michels M, Til MV (1994). Effects of heavy metals in soil on microbial diversity and activity as shown by the sensitivity- resistance. index, an ecologically relevant parameter. Biol. Fertil. Soil., 17: 177-184.

Essa AMM, Macaskie LE, Brown NL (2002). Mechanisms of mercury bioremediation. Biochemical Soc. Transaction., 30: 4.

Eccles H (1995). Removal of Heavy Metals from Effluents Streams-Why Select a Biological Process? Int biodeterior Biodegredation, 35: 5-16.

Fitzgerald WF, Lamborg $\mathrm{CH}$ (2005). Geochemistry of mercury in the environment. In: Lollar Bs, editor. Treatise on Geochemistry. Environmental Geochemistry. Amsterdam. Elsevier, pp. 17-48.
Green-Ruiz C (2006). Mercury (II) Removal from Aqueous solutions by Nonviable Bacillus Sp. From a Tropical Estuary. Bioresource Technol., 7: 1907-1911.

Gupta N, Ali A (2003). Mercury Volatilization by R Factor Systems in Escherichia coli Isolated from Aquatic Environments of India. Curr. Microbiol., 48: 88-96.

Holtze MS, Nielsen P, Ekelund F, Rasmussen LD, Johnsen K (2005). Mercury affects the distribution of culturable species of Pseudomonas in soil. Appl. Soil Ecol., 31: 228-238.

Jan AT, Murtaza I, Ali A, Rizwanul Haq QM (2009). Mercury pollution: an emerging problem and potential bacterial remediation strategies. World J. Microbiol. Biotechnol., 25: 1529-1537.

Jaysankar De, Ramaiah N, Mesquita A, Nerlekar X (2003). Tolerance to Various Toxicants by Marin Bacteria highly Resistant to Mercury. J. Mar. Biotechnol., 5: 185-193.

Jaysankar De, Ramiaiah N (2007). Characterization of marine bacteria highly resistant to mercury exhibiting multiple resistances to toxic elemicals. Ecol. Indicators., 7: 511-520.

Karbasizadeh V, Badami N, Emtiazi G (2003). Antimicrobial Heavy Metal Resistance and Plasmid Profile of Coliforms Isolated from Nosocomial Infections in a Hospital in Isfahan, Iran. Afr. J. Biotechnol., 2(10): 379-383.

Korenevskii AA, Sorokin VV, Karavaiko GI (1997). Interaction of RareEarth Metal ions with Candida utilis Cells. Mikarobiologya, 66: 198205

Leung M (2004). Bioremediation: Techniques for Deaning up Emess. J. Bioteach., 2: 18-22.

Leung WAC, Chua H, Lo W (2001). Biosorption of Heavy Metals by Bacteria Isolated from Activated Sludge. Appl. Biochem. Biotechnol., pp. 91-93.

Lopez Errasquin E, Vazquez C (2003). Tolerance and uptake of heavy metals by Trichoderma atroviride isolated from sludge. Chemosphere, 50: 137-143.

Miretzky P, Fernandez Cirelli A (2009). Hg(II) removal from water by chitosan and chitosan derivatives: A review. J. Hazardous Mater., 167: 10-23.

Nakamura K, Silver S (1994). Molecular analysis of mercury resistant Bacillus, isolated from sediment of Minamat bay, Japan. Appl. Enviorn. Microbiol., 66: 4596-4599.

Pahan K, Ray S, Gachui R, Chaudhuri J, Mandal A (1990). Ecological and Biochemical studies on mercury Resistance Bacteria. Indian. J. Environ. Health, 32(3): 250-261.

Patra M, Sharma A (2008). Mercury toxicity in plants. Bot. Rev., pp. 379-422.

Petrova MA, Mindlin S, Gorlenko Z, Kaliaeva E, Soina V, Bogdanova E (2002). Mercury resistance Bacteria from Permafrost Sediments and Prospects for their Use in Comparative studies of Mercury Resistance Determinants. Genetika, 38(11): 1569-1574.

Ramond JB, Berthe T, Duran R, Petit F (2009). Comparative effects of mercury contamination and wastewater effluent input on Gramnegative merA gene abundance in mudflats of an anthropized estuary (Seine, France): A microcosm approach. Res. Microbiol., 160: $10-18$.

Rehman A, Shakoori FR, Shakoori AR (2008). Uptake of heavy metals by Stylonychia mytilus and its possible use in decontamination of industrial wastewater. World J. Microbiol. Biotechnol., 24: 47-53.

Renzoni A, Zino F, Franchi E (1998). Mercury levels along the food chain and risk for exposed population. Environ. Res., 77: 68-72.

Ready D, Pratten J, Mordan N, Watts E, Wilson M (2007). The effect of amalgam exposure on mercury-and antibiotic-resistant bacteria. J. Antimicrob. Agents, 30: 34-39.

Robinson NJ, Whitehall SK, Cavet JS (2001). Microbial metallothioneins. Adv. Microb. Physiol., 44: 183-213.

Silver S, Ji G (1994). Newer systems for bacterial resistances to toxic heavy metals. Environ. Health Perspect., 102: 107-113.

Silver S, Phung LT (1996). Bacterial heavy metal resistance: new surprises. J. Ann. Rev. Microbiol., 32: 637-672.

Summers AO, Silver S (1978). Microbiological transformation of metals. J. Ann. Rev. Microbiol., 32: 637-672.

Singh S, Hyun Kang S, Mulchandani A, Chen W (2008). Bioremediation: Environmental clean-up through pathway engineering. Curr. Opin. Biotechnol., 19: 437-444. 
U.S.EPA (U.S.Environmental Protection Agency) (1997). Capsule Report. Aqueous Mercury Treatment. Office of Research and Development Washington D.C.

Wagner-Dobler I, Von Canstein H, Li Y, Leonhauser J, Deckwer WD (2003). Process Integrated Microbial Mercury Removal from Wastewater of chlor alkali Electrolysis Plants. J. Eng. Life Sci., 3(4): 177-181.
Wong PK, So CM (1993). Copper Accumulation by a Strain of Pseudomonas putida Microbios., 73: 113-121. (dentistry)\&action=edi. 